\title{
REFINING THE CHRONOLOGY AND OCCUPATION DYNAMICS OF THE MOUND VILLAGES OF SOUTH-EASTERN ACRE, BRAZIL
}

\author{
José Iriarte (iD $ه$ \\ University of Exeter - Department of Archaeology \\ Jonas Gregório de Souza iD \\ PhD.Arqueology, University Of Exeter \\ Mark Edward Robinson (D) $\triangle$
}

University of Exeter - Department of Archaeology

Antonia Damasceno Barbosa (D) $\triangle$

Franciele da Silva iD $\triangle$ 


\section{ABSTRACT}

This paper summarises recent test excavations at five Mound Village sites in the south-eastern sector of Acre state, Brazil, including Caboquinho, Boa Esperança, Tocantins, Dois Círculos IV and V. Radiocarbon dates obtained from the excavation of these sites refine the chronology of this archaeological tradition. To improve the chronologies of the mound villages in Acre for which radiocarbon dates were available, we modelled them using Bayesian statistics. Bayesian modelling of new radiocarbon dates from basal contexts of nine sites in the region establish the beginning of this archaeological tradition at $\sim \mathrm{AD}$ 952-1216. Nine dates from ten construction phases at the Caboquinho site establish the longest sequence from AD $1169-1309$ to colonial times. The stratigraphy of the test units reported in this study confirms previous results indicating that mounds are the result of alternating construction and occupation episodes. Dates from the Dois Círculos IV Rectangular Mound Village $\sim$ AD 1367-1451 indicates that Rectangular Villages are broadly contemporaneous with Circular Mound Villages. Single dates from three superimposed villages at Dois Círculos V suggest the succession of village construction. Overall, these preliminary results make a contribution to a better understanding of the timing of emergence and demise of Mound Village construction.

\section{REFINANDO A CRONOLOGIA E A DINÂMICA DE OCUPAÇÃO DAS ALDEIAS MONTANHOSAS DO SUDESTE DO ACRE, BRASIL}

Este artigo resume as escavações de teste recentes em cinco locais com aldeias de montículos no setor Sudeste do estado do Acre, Brasil, incluindo Caboquinho, Boa Esperança, Tocantins, Dois Círculos IV e V. As datas de radiocarbono obtidas da escavação neste local refinam a cro-nologia desta tradição arqueológica. Para melhorar a cronologia das aldeias de montículos no Acre para as quais as datas de radiocarbono estavam disponíveis, as modelamos usando esta-tísticas bayesianas. A modelagem bayesiana de novas datas de radiocarbono de contextos basais de nove locais na região estabelecem o início desta tradição arqueológica em 952-1216 DC. Nove datas de dez fases de construção no sítio Caboquinho estabelecem a sequência mais longa de 1169-1309 DC até a época colonial. A estratigrafia das unidades de teste relatadas neste estudo confirma resultados anteriores, indicando que os montículos são o resultado de episódios alternados de construção e ocupação. As datas da aldeia de montículos retangulares Dois Círcu-los IV 1367-1451 DC indicam que as aldeias de montículos retangulares são amplamente con-temporâneas às aldeias de monte circular. Datas únicas de três aldeias sobrepostas em Dois Círcu-los V sugerem a sucessão da construção de aldeias. No geral, esses resultados preliminares contri-buem para uma melhor compreensão do momento de emergência e morte da construção de aldeias de montículos.

\section{REFINANDO LA CRONOLOGÍA Y LA DINÁMICA DE OCUPACIÓN DE LAS ALDEAS DE MONTÍCULOS DEL SURESTE DE ACRE, BRASIL}

Este articulo resume las excavaciones de prueba recientes en cinco sitios de Mound Village en el sector sureste del estado de Acre, Brasil, incluidos Caboquinho, Boa Esperança, Tocantins, Dois Circulos IV y V. Las fechas de radiocarbono obtenidas de la excavación de este sitio refinan la cronología de esta tradición arqueológica. Para mejorar las cronologías de las aldeas de los montículos en Acre para las que se disponía de fechas de radiocarbono, las modelamos utilizando estadísticas bayesianas. El modelado bayesiano de nuevas fechas de radiocarbono de contextos basales de nueve sitios en la región establece el comienzo de esta tradición arqueológica en 952-1216 d.C. Nueve fechas de diez fases de construcción en el sitio de Caboquinho establecen la secuencia más larga desde 11691309 d.C. hasta la época colonial. La estratigrafía de las unidades de prueba reportadas en este estudio confirma resultados previos que indican que los montículos son el resultado de episodios alternados de construcción y ocupación. Las fechas de Dois Circulos IV Rectangular Mound Village 1367-1451 d.C. indican que las Aldeas Rectangulares son en general contemporáneas de las Aldeas de Circular Mound. Las fechas únicas de tres pueblos superpuestos en Dois Circulos V sugieren la sucesión de la construcción del pueblo. En general, estos resultados preliminares contribuyen a una mejor comprensión del momento de aparición y desaparición de la construcción de Mound Village.
Palavras-chave: Amazônia; Estado do Acre; Arqueologia Amazônica; Aldeias de montículos; Modelagem Bayesiana.
Palabras clave: Amazonas; Estado de Acre; Arqueología Amazónica; Pueblos De Montículos; Modelado Bayesiano. 


\section{INTRODUCTION}

Recent research has shown that the southern rim of Amazonia was inhabited by earthwork-building societies that engineered and domesticated entire landscapes during the Late Holocene, some of whom may be examples of low-density urbanism (Carson et al. 2014, Souza et al. 2018, Heckenberger et al. 2008, Iriarte et al. 2020, Prümers and Jaimes Betancourt 2014, Walker 2018). However, owing largely to the early stage of archaeological research in this vast region, the scale, timing, and intensity of human settlement for the most part still remain little explored. The Mound Villages, an archaeological tradition constituted by circular or rectangular arrangements of mounds interconnected by radiating roads, which was only discovered in the last decade, are a case in point.

Archaeological research into this culture is progressing, but there are still many questions that remain unanswered including: (i) when did the Mound Villages tradition actually begin, what was its rate of expansion, and when did they cease to be constructed? (ii) What were the occupation dynamics of mounds? (iii) Are Circular Mound Villages contemporaneous with Rectangular Mound Villages? (iv) What is the chronological succession of superimposed villages? The data presented in this article consist of the results of recent test excavations from five Mound Villages and a series of new AMS radiocarbon dates. New chronological data compiled with existing radiocarbon data from excavations in another five sites previously excavated allows us to determine better the beginnings, expansion, and demise of this cultural tradition.

\subsection{BRIEF ARCHAEOLOGICAL BACKGROUND OF THE MOUND VILLAGES OF ACRE STATE}

Mound Villages consist of circular, rectangular or elliptical arrangements of mounds surrounding a central plaza whence roads radiate in patterned directions. The tradition spreads from the Tapajós headwaters to the eastern and southern sectors of the Acre state, spanning over $1000 \mathrm{~km}$ (Souza et al. 2018, Iriarte et al. 2020, Saunaluoma, Anttiroiko, \& Moat 2019, Saunaluoma, Pärssinen, \& Schaan 2018) (Figure 1). Previously published dates from Acre suggest that they emerged $\sim 1000 \mathrm{AD}-$ after the Geoglyph formative ceremonial network was dissolved (Saunaluoma, Pärssinen, \& Schaan 2018). Currents radiocarbon dates temporally bracket the Mound Village occupation between AD 10001650 with the majority of dates falling between AD 1200-1500 (Souza et al. 2019). 


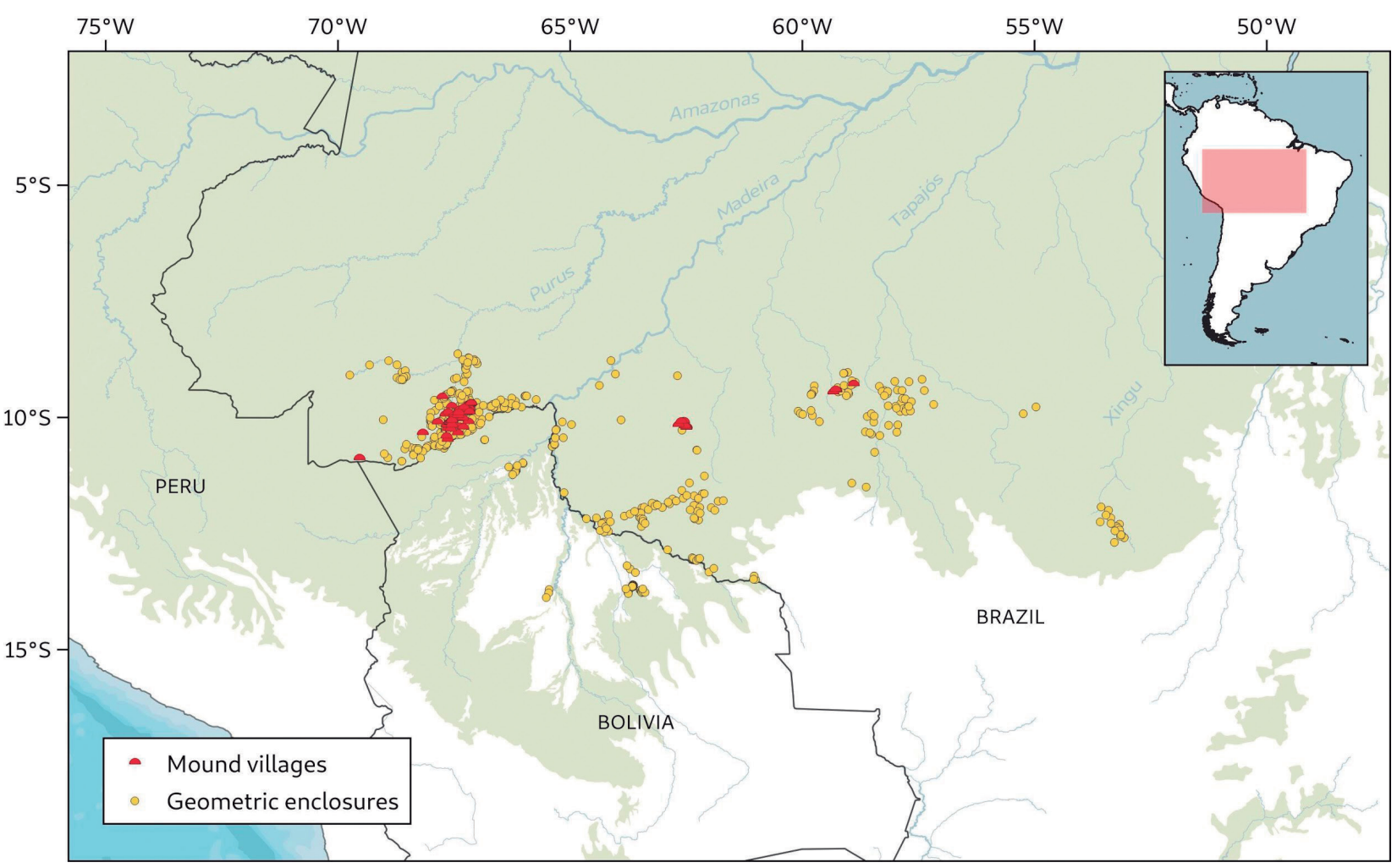

Figure 1 - Map of earthworks across the southern rim of the Amazon showing spatial dispersion of Mound Villages.

Currently, 51 Mound Villages have been documented using Lidar and satellite remote sensing in Acre alone (Iriarte et al. 2020). Based on their architectural design, in our previous work we have classified them into two major types: Circular Mound Villages and Rectangular Mound Villages (Iriarte et al. 2020) (Figure 2). Circular/ Elliptical ones are locally called Sóis (Suns) (e.g. Sol de Iquiri, Sol de Campinas) because, when seen from the sky, the sunken roads that depart from the circle of mounds resemble the rays of the sun. Circular Mound Villages are comparable to other circular villages across lowland South America (Heckenberger et al. 2008, Iriarte 2006, Schwarz \& Scott Raymond 1996, Wüst, \& Barreto 1999), but they exhibit several idiosyncratic features that set them apart from other known circular village traditions. Their singular features include ranked, paired, cardinally-oriented radial sunken roads exhibiting high embankments and elongated mounds (among other mound shapes) positioned around the circle like the marks of a clock. Within a certain variability, they exhibit a strikingly uniform and consistent construction. 
The arrangements, shapes, and sizes of the mounds in conjunction with radial road structures are repetitive and remarkably similar. The diameter of Circular Mound Villages ranges from $40 \mathrm{~m}$ to $153 \mathrm{~m}$ (average of $86 \mathrm{~m} ; \mathrm{n}=23$ ) with the area enclosed by the central plaza ranging from $\sim 0.12$ to $1.8 \mathrm{ha}$. Site size variation does not show any trends toward a bimodal distribution of site size that could clearly indicate a hierarchical settlement pattern. The number of mounds ranges from 3 to 32 mounds with the former cases most likely corresponding to sites that have been partly destroyed. They contain a diversity of mound shapes. Elongated dome-shape mounds are $20-25 \mathrm{~m}$ long, 1.5 to 3 $\mathrm{m}$ high, with their major axis radiating outwards from the centre of the circle of mounds. The mound slopes are steeper towards the village plaza and gradually fade away from the circle, forming what appear to be access ramps to the top of mounds. Along with the elongated mounds, these sites also exhibit larger platform mounds and conical mounds. The latter needs further investigation to understand their construction history and uses (Iriarte et al. 2020) .

Circular Mound Villages show a hierarchy of roads: Principal Roads and Minor Roads (Iriarte et al. 2020, Figure 6). Principal roads are deeper, wider (3-6 m), and exhibit higher banks. The majority of them exhibit two principal roads leaving in a northward direction (Principal Northern Roads) and two principal roads leaving in a southward direction (Principal Southern Roads). They generally run between 310-320 and 30-40 degrees range. The roads come closer together without connecting with each other as they approach the village. Generally, when the roads make contact with the village the banks became higher and wider. They cut through the mounds producing a rather straight mound profile and/or creating a double-L-shaped feature as a prolongation of the banks. These mounded structures are generally taller than the rest. Circular Mound Villages are also often cut by an EW Principal Road. Principal roads become narrower as they move away from the site. Although they run separated close to the village, away from the village, they can reconnect forming a single trail (Iriarte, et al. 2020, figure 10). Circular Mound Villages also usually exhibit minor roads that lead to the closeby streams. In general, Minor Roads are shorter and usually connect to nearby streams.

Mound Villages are generally located on the top of small, flat plateaus overlooking a stream to which they connect by a road. They are closer to navigable rivers than Geoglyphs. An examination of site size distribution, elaboration and standardisation of their mounded architecture point to the lack of clear differences between 
sites, with no apparent signs of centralisation with distances of 2.5-3 km and 5-6 km between or hierarchical settlement patterns (Iriarte et al. sites. Where lidar data is available on sectors of the 2020). Taking the study region as a whole, Mound landscape that have not been modified by modern Villages do not show a regular spatial distribution; settlement and agriculture, villages are shown to however, some small groups of villages positioned be interconnected by roads with low banks that along streams do appear to be regularly spaced, are up to $5 \mathrm{~km}$ long (Iriarte et al. 2020).

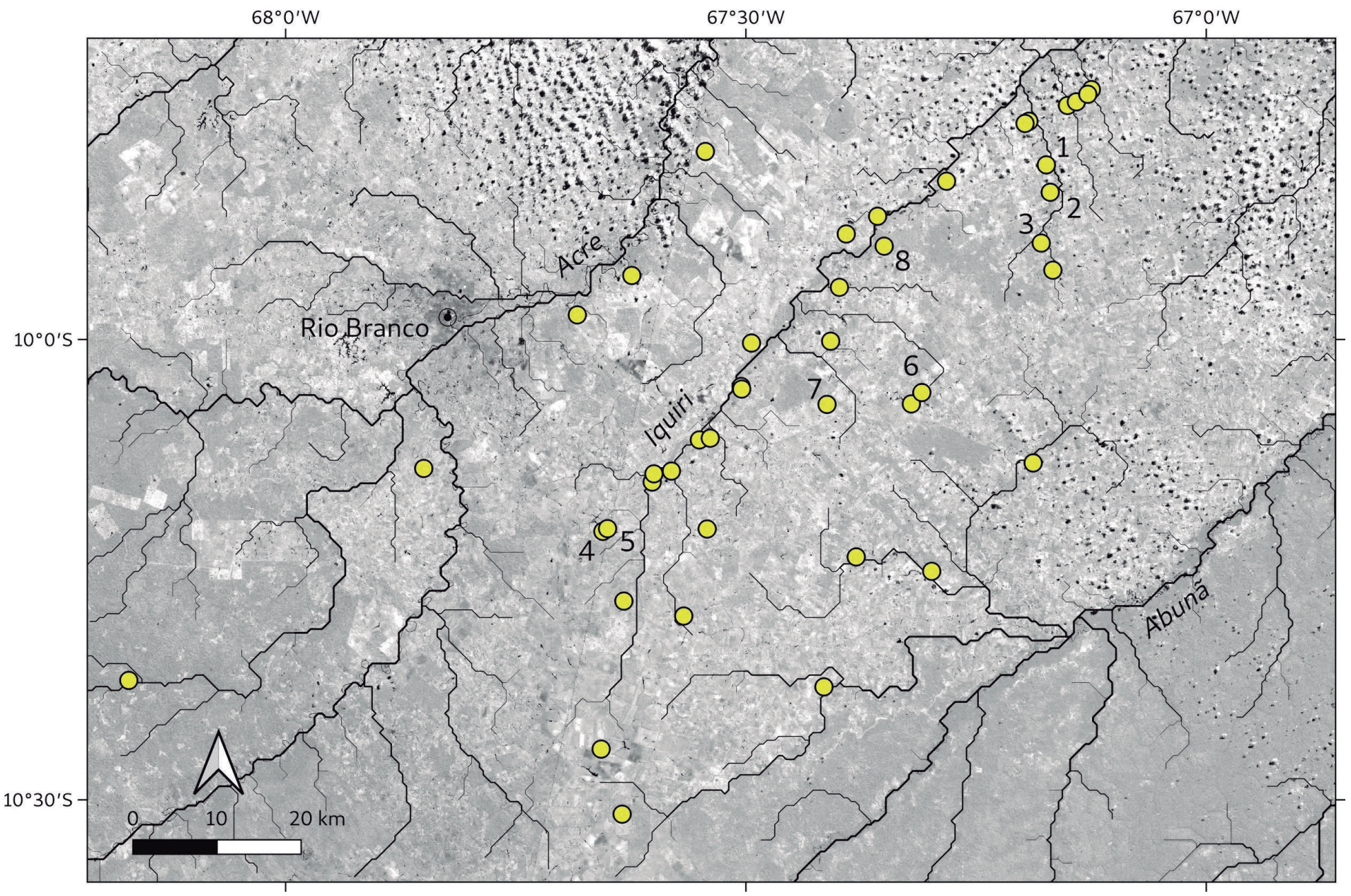

Figure 2 - Map of the study region showing the spatial distribution of Mound Villages and sites where archaeological excavations have taken place: 1) Caboquinho; 2) Boa Esperança; 3) Tocantins;

4) Dois Círculos IV; 5) Dois Círculos V; 6) Sol de Campinas; 7) Fazenda Iquiri III. 
Previous excavations at the mounds revealed discrete layers interpreted as alternating construction and occupation episodes (clear occupation strata with domestic features) as well as adjacent middens, confirming the nature of the sites as settlements (Neves et al. 2016, Saunaluoma, Pärssinen, \& Schaan 2018). Construction layers are generally thicker, contain decomposed laterite, lack charcoal, ceramics and macrobotanical remains and are less compacted than occupation layers, which are thinner, darker, and contain larger quantities of artefacts and ecofacts. Mounds may contain more than 10 occupation layers intercalated with construction events (Neves et al. 2016). Due to the fact that research in Mound Villages is still in its beginnings, little is known about their portable material culture, but preliminary data show differences relative to the ceramics of the geoglyphs and other ringditch traditions: in Riberalta, Bolivia, mound village ceramics are distinguished by red-painted geometric designs on a white-slipped surface (Saunaluoma 2010). Archaeobotanical analysis has only been conducted at one site, Sol de Campinas. It documented the presence of maize (Zea mays), Brazil nuts (Bertholletia excelsa), passion fruit (Passiflora edulis), muruci (Byrsonima crassifolia), tucuma or murumuru palms (Astrocaryum sp.) and Chenopodiodeae seeds (Neves et al. 2016).
Increase in maise fragment frequency is associated with an increase in charcoal macroremains on occupation surfaces and both sharply decrease in construction layers.

\section{METHODOLOGY}

We carried out excavations in five Mound Villages, including Caboquinho, Boa Esperança, Tocantins, Dois Círculos IV and Dois Círculos V (Figure 2). In general, test excavations targeted the tallest and better-preserved mounds within the Mound Villages with potential for the longest and most complete stratigraphic profiles. In sites with superimposed villages, such as Dois Círculos $\mathrm{V}$, we conducted test excavations in adjacent villages to compare chronologies. Mound outlines were delineated from our survey of the sites and digitised from the lidar data.

Excavation focused on the identification of discrete archaeological contexts that have a unique formation process. This may relate to a stratigraphic horizon, a post hole, a burial, a fire pit, etc. Each context was assigned a unique, arbitrary context "C" number (e.g C1, C7, C13). All material recovered from each context was analysed separately. This system facilitates the separation of archaeological event during excavation and enables a clear identification of the relative chronological 
separation of events, ensuring that material from different deposits are not mixed. This is crucial for understanding changes within an assemblage and especially in respect of environmental sampling of contexts.

To better constrain the chronologies of the mound villages in Acre for which radiocarbon dates were available, we modelled them using Bayesian statistics. We performed the analysis in ChronoModel, which is better suited for regional models than other commonly used software like OxCal (Banks 2015, Banks et al. 2019, Binder et al. 2017). ChronoModel employs a hierarchical "Event model", which seeks to estimate the date of a context (event) based on individual dates (Lanos $\&$ Philippe 2017). Events can be further constrained by stratigraphic order and incorporated into multiple phases based on different criteria. One of the advantages of this approach is that the same event may belong to more than one phase, e.g. one for its archaeological site and another for its archaeological culture. Sample contamination, old charcoal or other sources of disturbance may result in a measured age that is earlier or later than the context of deposition, and software like OxCal have different models to deal with such outliers (Ramsey 2009). Outlier detection, however, is not necessary in ChronoModel, which automatically penalises measurements that are far from the target event date or in disagreement with the stratigraphy, providing results that are more robust than other software packages (Banks et al. 2019).

\section{RESULTS}

\subsection{EXCAVATIONS}

\subsubsection{CABOQUINHO}

Caboquinho is an elliptical mound village with a maximum diameter of $84 \mathrm{~m}$. The site has a total of 26 mounds, some of which form a semicircle inside the plaza area. Two main sunken roads depart approximately to the north and south of the village, their embankments fused with the edges of the adjacent mounds. The road to the north connects with the Dona Maria Mound Village, while the road to the south connects with the Boa Esperança site (Iriarte et al. 2020, Figs. 10-11) (Figure 3).

Two units were excavated at Caboquinho. Unit 1 was a 2 x 1.5 m excavation on top of the largest mound at the site, on the northeast edge of the main plaza. The excavation was reduced to $2 \times 1$ $\mathrm{m}$ to provide an access step after a metre depth. The top of the mound is $170 \mathrm{~cm}$ above the current ground surface. The excavation documented 25 contexts $(\mathrm{C})$ and revealed ten construction phases over approximately $170 \mathrm{~cm}$, with eroding bedrock encountered at $210 \mathrm{~cm}$. The soil is predominantly 


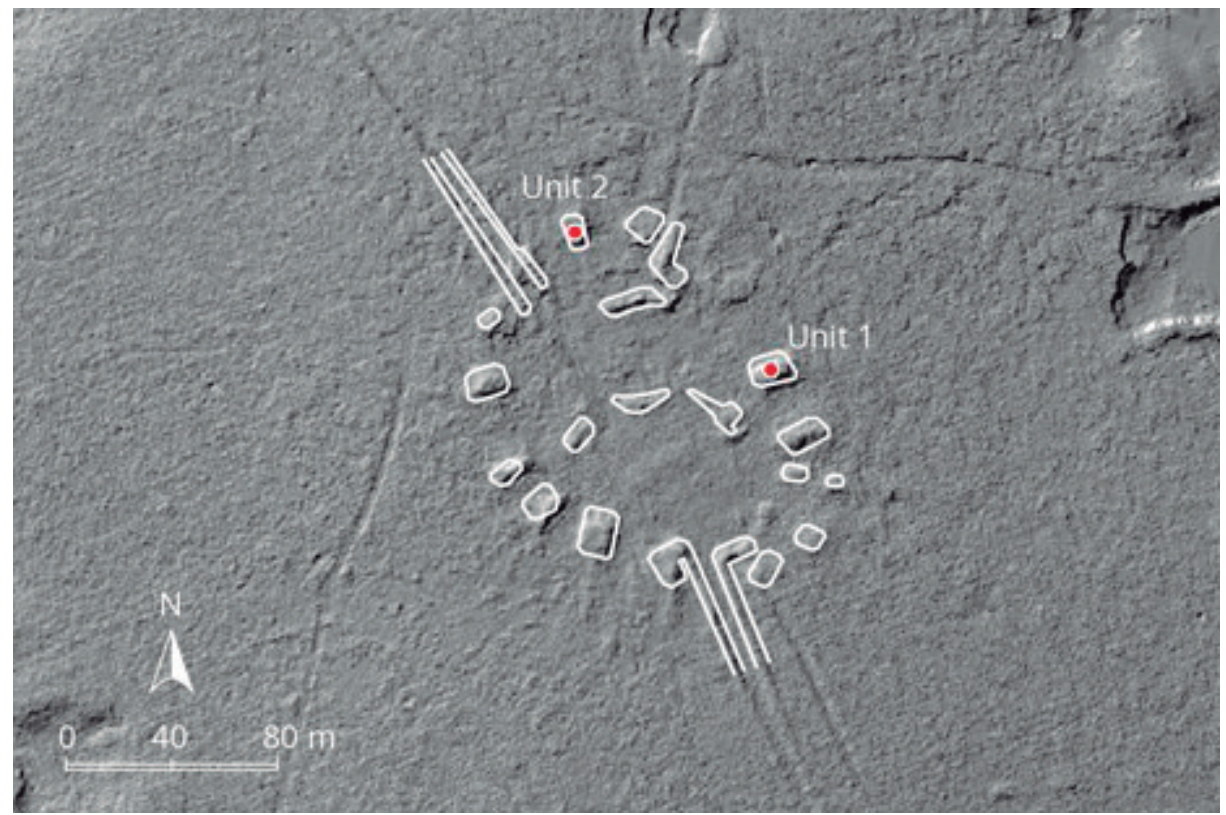

Figure 3 - Lidar image of the Caboquinho Mound Village showing the location of test units.

a sandy clay loam. The three earliest floors were burnt. Thermal features are present on four of the surfaces. The upper strata are devoid of features and are generally thicker layers. The lower strata are also richer in ceramic material.

\section{STRATIGRAPHY OF UNIT 1 (FIGURE 4)}

\section{C25: Eroding bedrock. 7.5 YR 5/8.}

C24-C22: Stratified natural subsurface. The surface of C22 was the original ground surface, with some mixing into C23. C24 is a sterile natural above the bedrock. The base of fire pit $\mathrm{C} 15$, associated with the surface of $\mathrm{C} 14$, continues into C22.
C21: Burnt, compacted surface that represents the first occupation of the mound. The burnt matrix may reflect the clearance of vegetation in the area. The impacts of $\mathrm{C} 15$ fire pit are seen in the north of the excavation, as is the baked clay of $\mathrm{C} 17$, a thermal feature associated with C13 surface. C20, present on the surface of $\mathrm{C} 21$, adjacent to $\mathrm{C} 17$, is a focused concentration of charcoal.

C19: Compacted surface, representing the second construction phase and including four discreet thermal features. A small concentration of charcoal, C18, was adjacent to C17, although in a slightly different location to C20. A fire pit (C16) was also present in the east of the excavation. The 
C19 matrix incorporates a higher proportion of charcoal, as compared to the upper strata.

C14: The compacted surface of C14 may have been burnt. C15 and C17 features are characterised by baked clay with distinct colouration and a brittle matrix. Charcoal was collected from both features.

C13: Fourth construction. The construction lacks burning, unlike the lower strata, and is also the start of deeper fill material for each construction phase. Two shallow fire pits were present on the surface (C11 and C12). Orange matrix. 7.5 YR 4/6.

C7: Fifth construction phase. The surface was burnt. Three small fire pits were present on the surface of $\mathrm{C} 7$ (C8, $\mathrm{C} 9$ and $\mathrm{C} 10)$. The excavation was reduced to a $2 \times 1 \mathrm{~m}$ unit after C7 surface. levels.

\subsection{YR 4/4.}

C6: Sixth construction phase. The surface of C6 is littered with flecks of charcoal and a few ceramic sherds. 7.5 YR 4/6.

C5: Seventh Construction. The compacted surface has flecks of charcoal. The fill is orange sandy clay. 7.5 YR 4/4.

C4: Eighth construction. Roots disturbance the surface of $\mathrm{C} 4$ and create a slightly uneven surface, although the surface is distinct from the softer fill above and below. 7.5 YR 4/4.

C3: Ninth construction. The surface and fill have extensive root disturbance. The fill is composed on a loose sandy clay. 10 YR 5/4.

C2: Tenth and final construction phase. The surface of C2 is hard packed sandy clay. 10 YR 5/3. The layer is one of the largest additions, although has not suffered the same compaction as lower

C1: Topsoil and modern grass vegetation. 7.5 YR 3/2. There is evidence of modern burning on the surface.
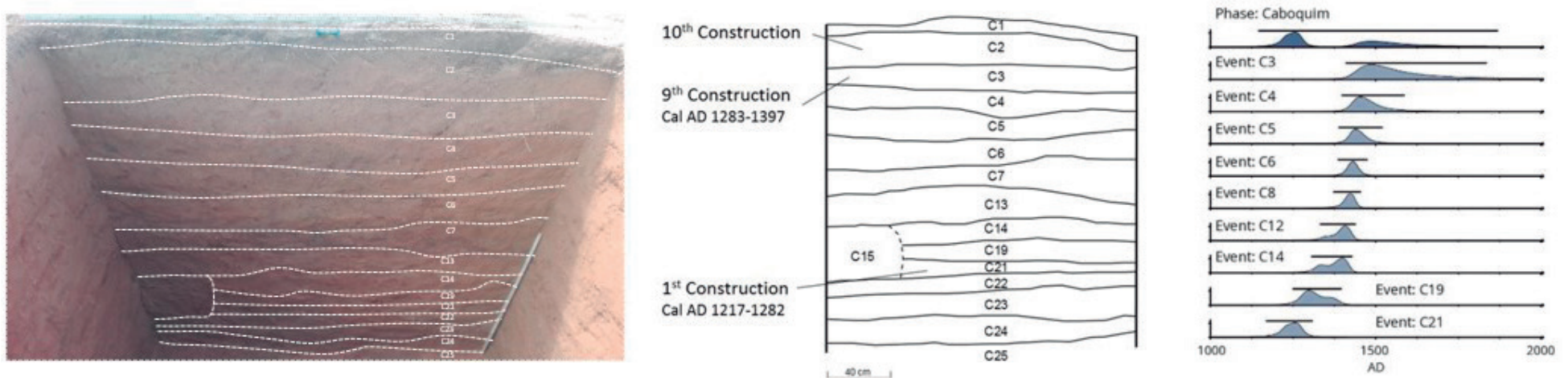

Figure 4 - Sketch stratigraphy profile of Caboquinho Test Unit 1 with associated radiocarbon dates. 


\subsubsection{BOA ESPERANÇA}

Boa Esperança is a Circular Mound Village constituted by fourteen mounds enclosing $0.55 \mathrm{ha}$, which is located about $\sim 2.5 \mathrm{~km}$ south of Caboquinho (Figure 5).

Two test units were excavated at the site. Unit 2 is a $2 \times 1 \mathrm{~m}$ excavation on top of a mound on the NE side of the ring village. The adjacent mound, anti-clockwise, is the northern mound, the largest at the site. Excavation documented nine different contexts and revealed three construction phases, over approximately $60 \mathrm{~cm}$. The mound top is approximately $45 \mathrm{~cm}$ above the current ground surface. Ceramic material was collected from all constructed layers, with an abundance of sherds in the fill material of the first two construction phases, and far fewer sherds in the final construction fill and within the modern topsoil. The excavation reveals the incremental growth of the mound and features a burnt post associated with the first mound construction.

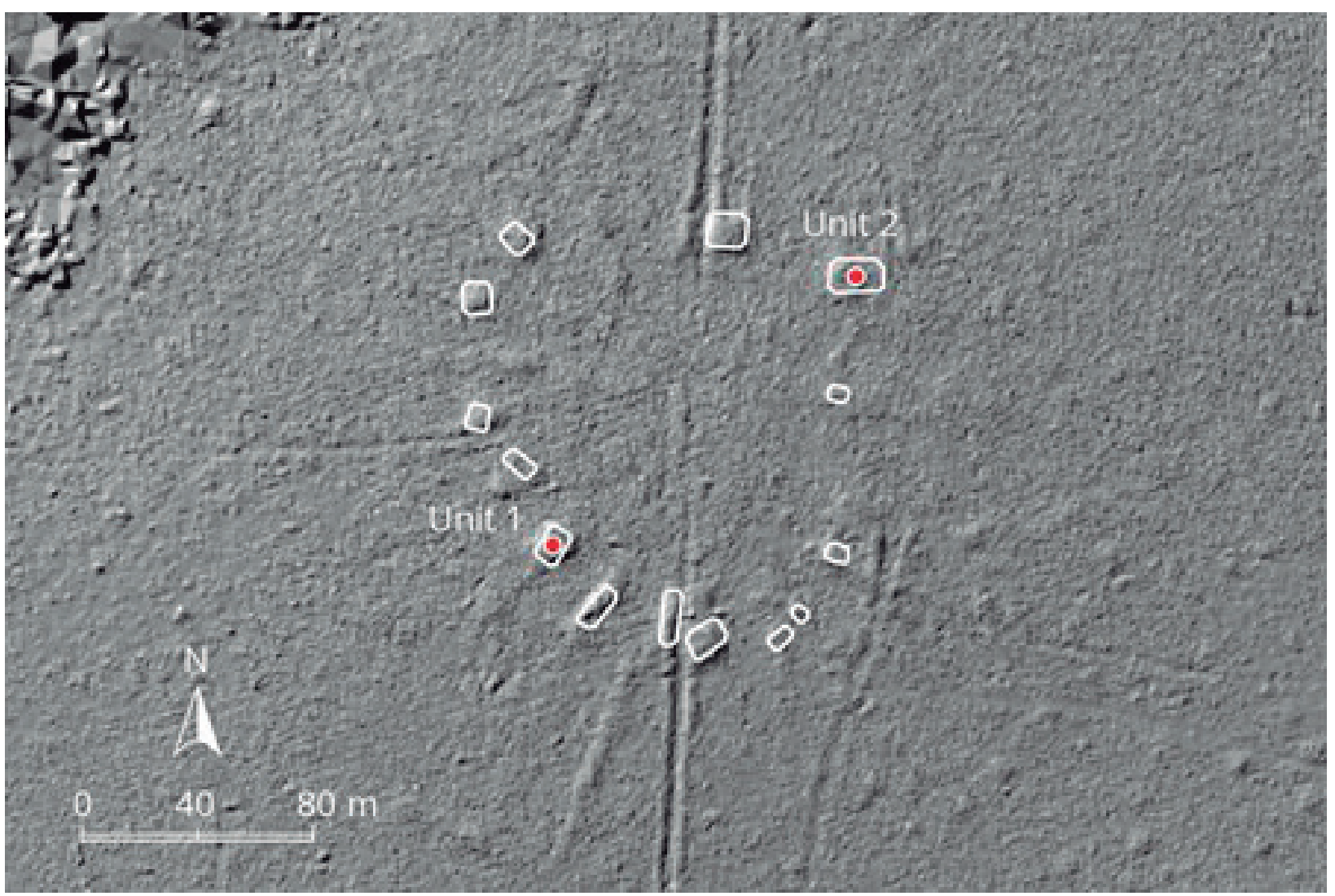

Figure 5 - Lidar image of Boa Esperança showing the location of test units. 


\section{STRATIGRAPHY UNIT 2 (FIGURE 6)}

C9: Hard packed, sterile natural. Plastic clay. 5YR 4/6.

C8: Natural plastic clay with some mixing from above. 5YR 4/6.

C6: The top of C6 is the initial ground surface. The matrix is darker, likely due to organic components from vegetation and possible burning during land clearance. 7.5 YR 2.5/2. A concentration of charcoal (C7) on the surface of C6 may be from vegetation clearance or a discreet fire pit. The continuation of a post hole (C4) associated with C5 surface is present in the matrix.

C5: The first mound construction. The initial mound was fairly low (less than $20 \mathrm{~cm}$, after compaction). The fill material is a mottled orange silty clay. 7.5YR 3/4. A post hole (C4) on the surface of $\mathrm{C} 5$, shows that the post was burnt before the second mound construction phase (C3), with the fill material of $\mathrm{C} 3$, covering the burnt stub of the C4 post.

C3: The second mound construction added 20 $\mathrm{cm}$ to the height of the mound. The fill material was slightly darker (5YR 4/6) and did not include the mottled material of $\mathrm{C} 5$.

C2: The third and final construction phase added $30 \mathrm{~cm}$ to the mound height. 5YR 4/6. The orange clay is slightly lighter and has far fewer artefacts included.

C1: Thin modern organic-rich topsoil and grass cover. Some compaction from cow traffic and baking from sun exposure.

\section{Burnt Patch}

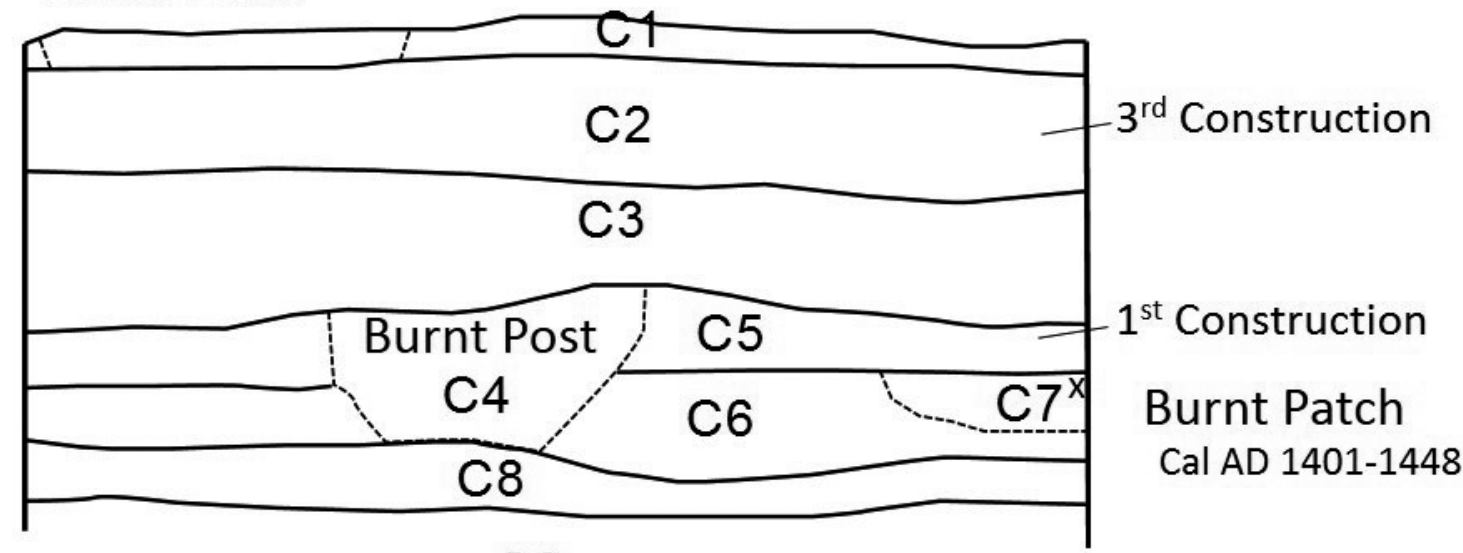

$40 \mathrm{~cm}$

C9

Figure 6 - Sketch stratigraphy profile of Boa Esperança, Unit 2. 


\subsubsection{FAZENDA TOCANTINS}

Fazenda Tocantins is an elliptical Mound Village constituted by 18 mounds that enclose 0.6 ha. Two test units were excavated at this site (Figure 7). Unit 1 was a $2 \times 1 \mathrm{~m}$ excavation on the top of a ridge mound on the southeast side of the ring village. An ancient road enters the site on the other side of the next mound to the south. The excavation revealed four construction phases. The soil is a clay loam throughout the profile.

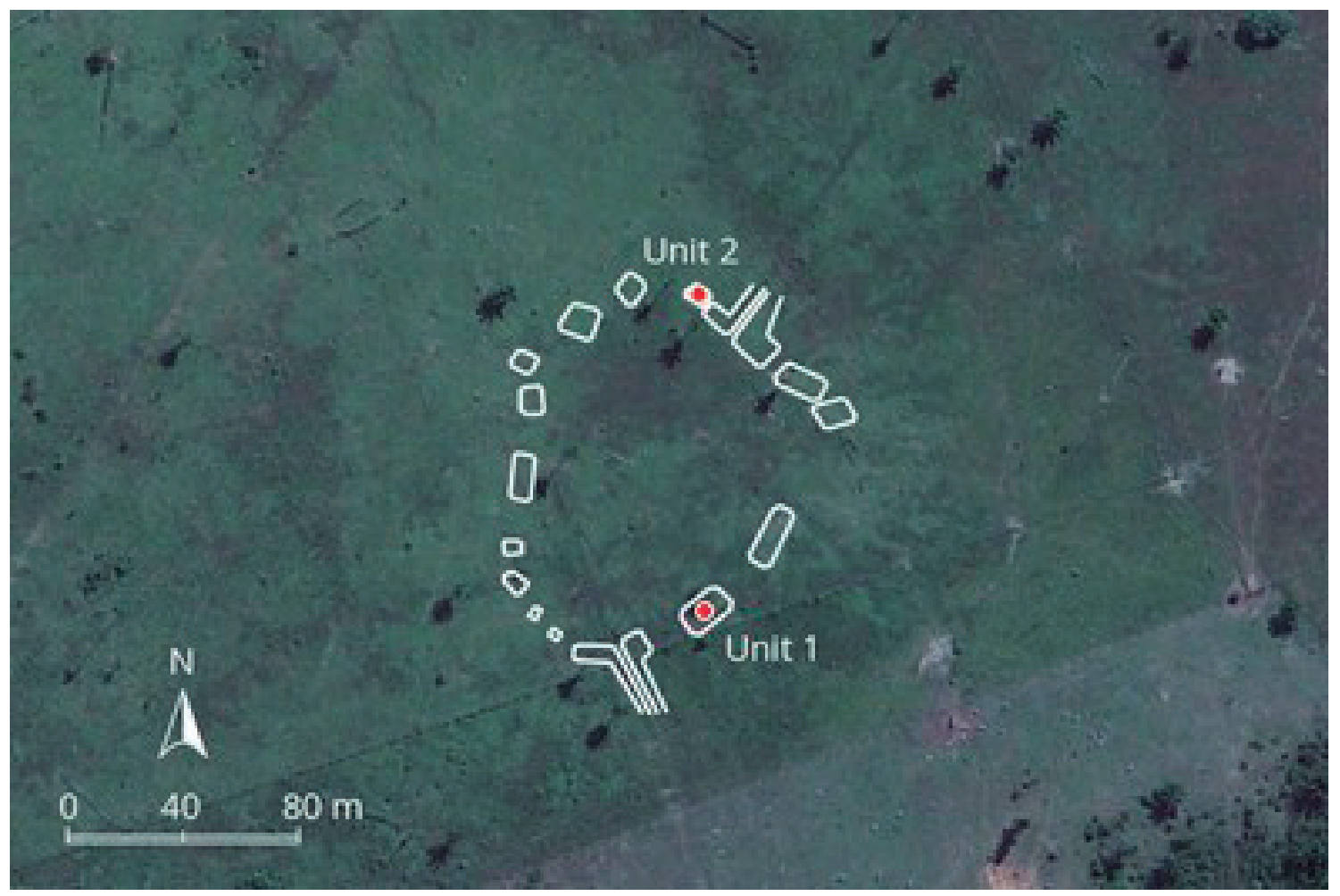

Figure 7 - Google image of Fazenda Tocantins showing the location of test units.

\section{STRATIGRAPHY OF UNIT 1 (FIGURE 8)}

C8: Mottled clay natural soil.

C7 and C6: Natural subsoil and original ground surface. Burning is present on the surface of $\mathrm{C} 6$, likely from the vegetation clearance before mound construction. Ceramics are present on the surface of C6, with charcoal flecks concentrated in the north of the excavation. Some ceramic material is present in the C6 matrix, which likely was mixed in through bioturbation. 
C5: First mound construction. The surface of C5 is constructed of compacted clay, with the fill of C5 composed of loose clay fill with a small amount of ceramics.

C4: Second construction phase. The surface of $\mathrm{C} 4$ is highly disturbed by roots, with large disturbances creating a very loose matrix in the north and south of the excavation. Ceramics and charcoal are present in the fill.

C3: Third construction phase. Modern roots are extensively present on the surface of $\mathrm{C} 3$ and causing disturbance to the fill. A few ceramics are present within the fill.

C2: Fourth and final construction. The surface of $\mathrm{C} 2$ is hard compacted clay, with modern trampling and baking from the sun adding to the compaction. The fill is heavily disturbed by roots. Charcoal and ceramics are present throughout the fill material, although charcoal may result from modern burning and bioturbation.

C1: Modern topsoil. Thin layer of organic topsoil and grass cover. No artefacts are within the topsoil.

\subsubsection{DOIS CÍRCULOS IV}

Dois Círculos IV is a Rectangular Mound Village located in the centre of a complex of geoglyphs and rectangular annexes. The site is located in between the two circular geoglyphs. It is constituted of 16 mounds enclosing an area of 0.7 ha (Figure 9).
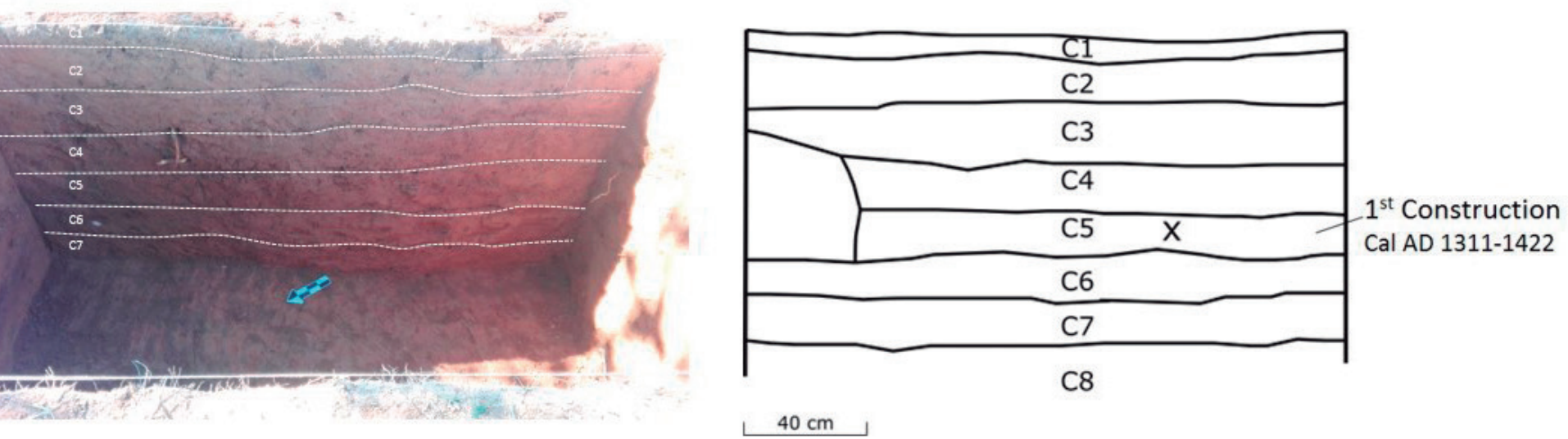

Figure 8 - Sketch stratigraphy profile of Tocantins, Unit 1. 


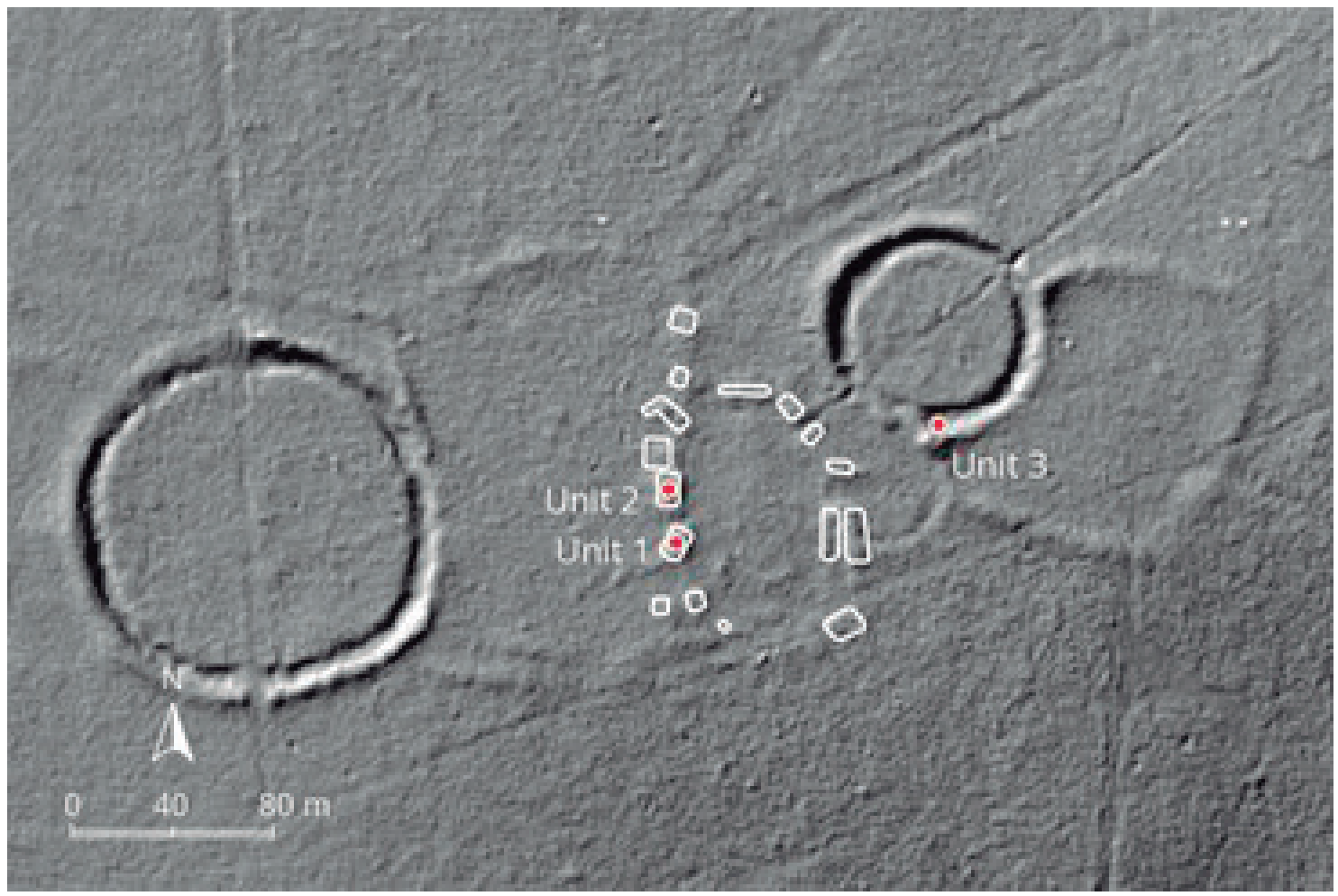

Figure 9 - Lidar image of Dois Círculos IV showing the location of test units.

Unit 1 is a $2 \times 1 \mathrm{~m}$ excavation on top of a ridge mound in the western side of the ring village. The ring village is situated between two geoglyphs. The top of the mound is $85 \mathrm{~cm}$ above the modern ground surface. Two construction phases were evident from the excavation. The soil is very sandy, and far redder compared to all other sites excavated. The two construction phases are larger than most of the phases seen at other sites, adding over $20 \mathrm{~cm}$ to the height of the mound each time. The geoglyphs are likely to be far older than the ring village, which probably had a substantial impact on the landscape before the mound construction. The dark soil at the base of the mound construction suggests the area was cleared with fire; however, this may have been a repeated action over the lifespan of the geoglyphs, before the mound construction. Dating of charcoal from the strata within Unit 1 and from the two geoglyphs will help resolve the landscape history. 


\section{STRATIGRAPHY OF UNIT 1 (FIGURE 10)}

C7: Compacted sterile sandstone. 2.5 YR 3/4.

C6: Natural subsoil with some mixing from above, including two ceramic sherds. 2.5 YR 4/6.

C5: More gritty subsoil with limited ceramic material, likely mixed from above. The top of $\mathrm{C} 5$ is mottled with orange and red and does not appear to have been exposed as a surface. 5 YR 3/4.

C4: The surface of C4 was likely the original ground surface. The surface and matrix are darker than all other strata, indicating a higher organic component and likely burning to clear the landscape. Few ceramics are present within the matrix of $\mathrm{C} 4$.

C3: First mound construction. The surface was distinct in compaction from $\mathrm{C} 2$ fill. Ceramics are present in the loose fill, which is disturbed by roots.

C2: Second and final construction phase. The soft sandy clay fill of C2 is full of ceramics, resulting in one of the highest ceramic densities encountered during the 2018 excavations. There is also a distinctly high proportion of larger ceramic sherds as compared to the other site assemblages. 5 YR 3/4.

C1: Modern topsoil. Thin layer of organic top soil and grass vegetation. 5 YR 3/3.
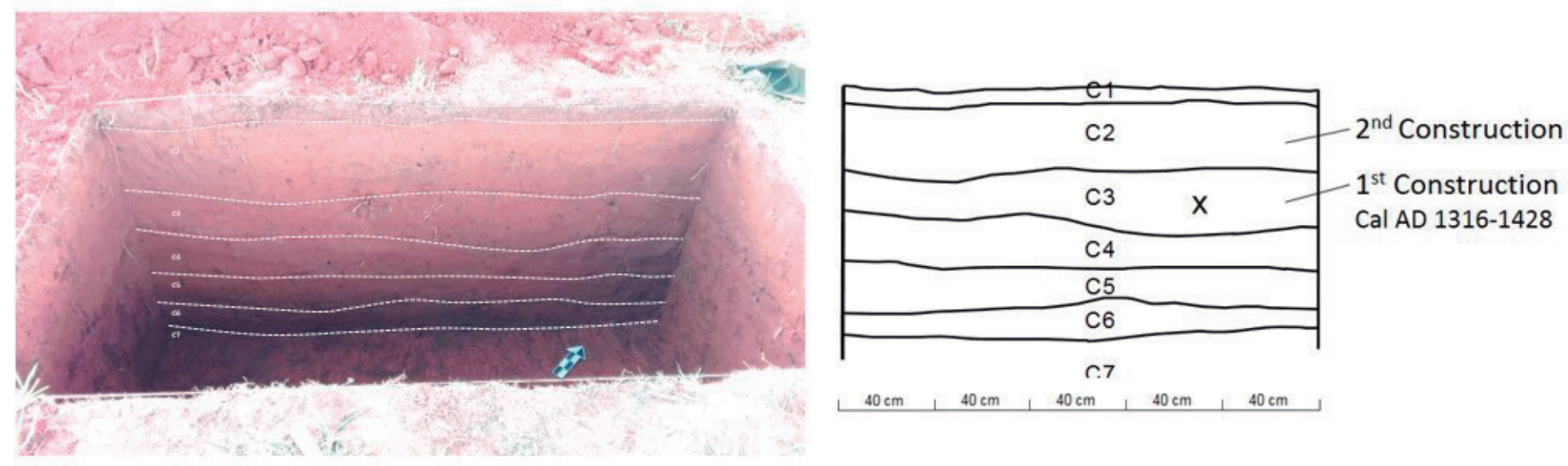

Figure 10 - Sketch stratigraphy profile of Dois Círculos IV, Unit 1. 


\subsubsection{DOIS CÍRCULOS V}

Dois Círculos V is a complex of what appear to be three superimposed elliptical villages located about $500 \mathrm{~m}$ to the north east of Dois Círculos IV.

In total, the site is constituted by 32 mounds that overall encloses an area of 0.68 ha (Figure 11).

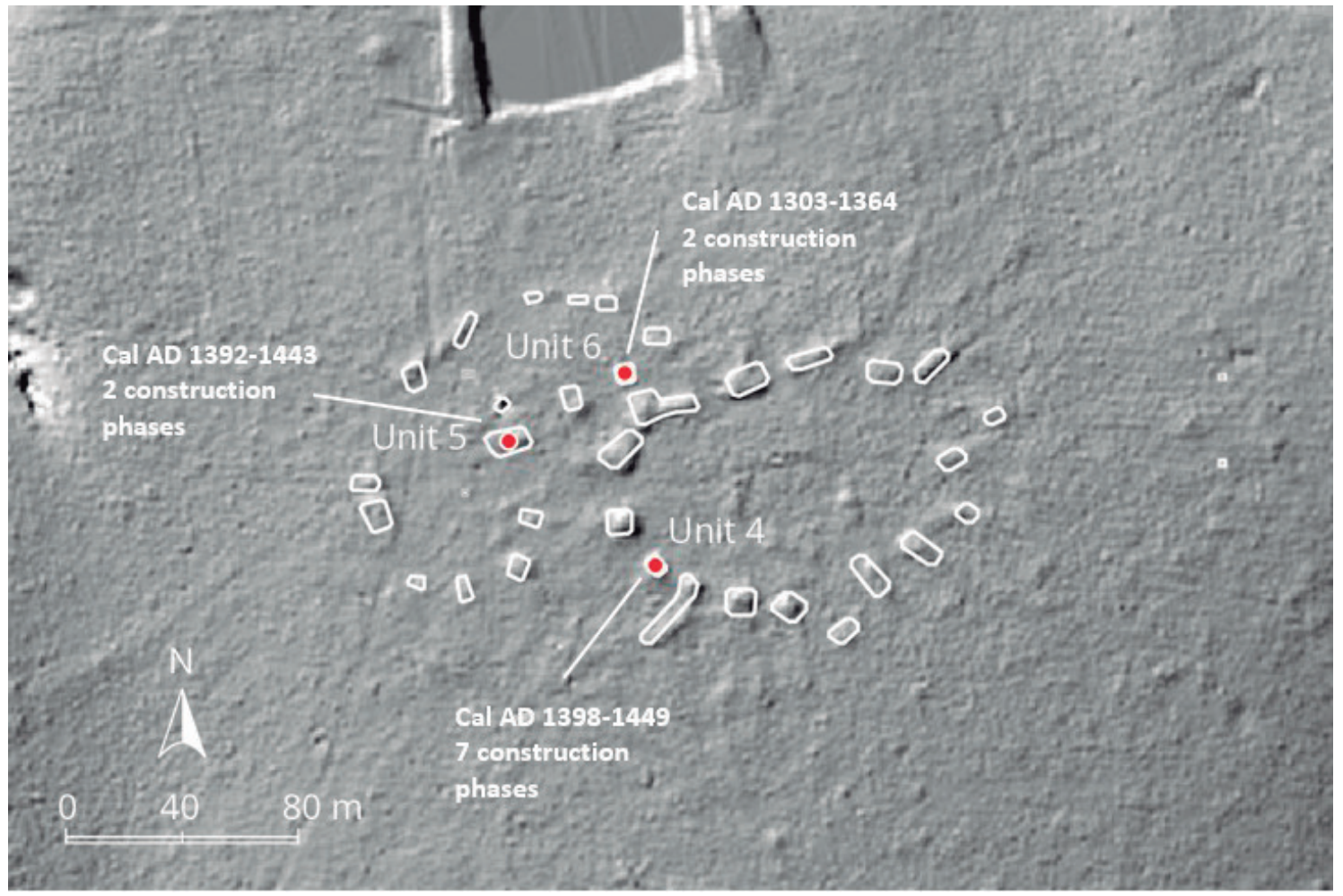

Figure 11 Lidar image of Dois Círculos V showing the location of test units and radiocarbon dates from test units.

STP 4

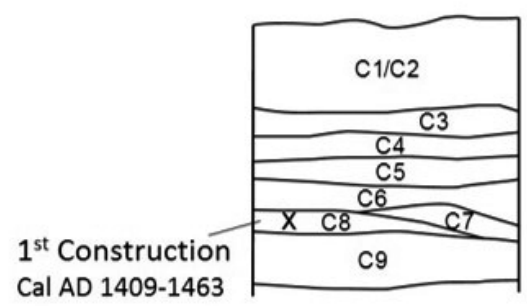

$10 \mathrm{~cm}$
STP 5

\begin{tabular}{|c|}
\hline $\mathrm{c} 1$ \\
\hline $\mathrm{c} 2$ \\
\hline $\mathrm{x} \frac{\mathrm{C} 3}{\mathrm{c} 4}$ \\
\hline $\mathrm{C} 5$ \\
\hline
\end{tabular}

STP 6

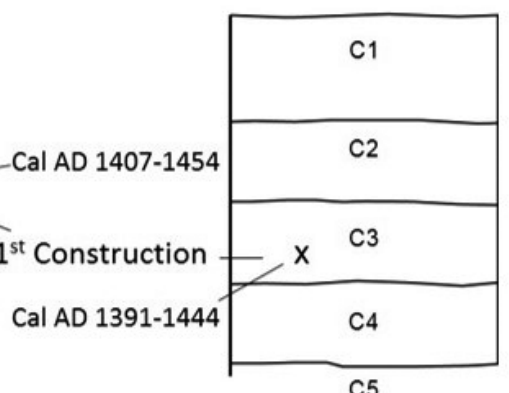

Figure 12 - Sketch stratigraphy profile of Dois Círculos V, Units 4, 5 and 6. 
The lidar image in Figure 11 hints to the superimposition of three villages. Based on the limited testing and available radiocarbon dates it appears that the first construction event of mound village C (Shovel Test Unit 6) is a bit older (about $\mathrm{AD} 1303-1344)$ than the one from mound village B, Shovel Test Unit 5 (about AD 1342-1443) and mound village A, Shovel Test Unit 4 (about AD 1398-1449). These preliminary results suggest that the site started with a smaller village that later expanded into a larger one.

\subsection{CHRONOLOGY}

Using the intersecting phase structure of ChronoModel, we built separate phase models for each archaeological site and simultaneously incorporated all dates into a single phase for the mound village tradition (Figure 13). Events were mostly defined based on single dates, but when multiple dates were obtained from an excavation unit, further constraints were added by ordering them based on their stratigraphic sequence. In Figure 13, probability densities refer to the modelled date when a single radiocarbon measurement was available (e.g. Dois Círculos, Tocantins) or to the modelled boundaries for the beginning and end of the sequence when multiple measurements were available (e.g. Caboquim, Sol de Campinas). These probabilities are reported in Table 3. Individual sites are modelled by considering each site's measurements as belonging to a separate phase. As ChronoModel allows for simultaneously modelling all radiocarbon dates as belonging to the same phase (Mound Villages), we are able to estimate the start and end boundaries for the Mound Villages tradition (Figure 13, Table 3).

The results show that mound villages emerged $\sim \mathrm{AD}$ 952-1216, with the earliest dates coming from Sol de Campinas (Table 3). Our longest sequence comes from Caboquinho, where we obtained nine AMS measurements from Unit 1, placed on one of the highest mounds on the eastern side of the village (Figure 4). Out of the ten construction phases of the mound, nine were dated. Although measurements apparently show some inversions, Bayesian modelling allows the estimation of the event dates in correct chronological order (Figure 4, Table 1). The basal event (C21) has a posterior date of AD 1169-1309, placing it among the earliest mound villages dated so far, with continuous occupation until colonial times (1403-1834) (Table 1). 


\begin{tabular}{|c|c|c|c|c|c|}
\hline Context & $\begin{array}{c}\text { Laboratory } \\
\text { number }\end{array}$ & Depth $(\mathrm{cm})$ & C14 BP & $\begin{array}{c}\text { Unmodelled cal } \\
\text { AD }(2 \sigma)\end{array}$ & $\begin{array}{c}\text { Posterior event } \\
\text { date }(95 \%)\end{array}$ \\
\hline C3 & Beta-500920 & 48 & $640 \pm 30$ & $1283-1397$ & $1403-1834$ \\
\hline C4 & Beta-500921 & 58 & $540 \pm 30$ & $1316-1437$ & $1398-1588$ \\
\hline C5 & Beta-500922 & 78 & $740 \pm 30$ & $1224-1291$ & $1387-1519$ \\
\hline C6 & Beta-500923 & 98 & $510 \pm 30$ & $1328-1445$ & $1385-1473$ \\
\hline C8 & Beta-500924 & fire pit & $470 \pm 30$ & $1410-1457$ & $1372-1454$ \\
\hline C14 & Beta-500925 & fire pit & $580 \pm 30$ & $1300-1419$ & $1332-1438$ \\
\hline C19 & Beta-500926 & 125 & $490 \pm 30$ & $1404-1450$ & $1306-1429$ \\
\hline C21 & Beta-500928 & 145 & $770 \pm 30$ & $1217-1282$ & $1169-1309$ \\
\hline
\end{tabular}

Table 1 - AMS measurements from Caboquinho and posterior event dates modelled with ChronoModel.

\begin{tabular}{|c|c|c|c|c|c|}
\hline Site & Unit & Context & Laboratory number & C14 BP & $\begin{array}{c}\text { Unmodelled } \\
\text { cal AD }(2 \sigma)\end{array}$ \\
\hline Boa Esperança & 2 & C7 & Beta-500913 & $540 \pm 30$ & $1316-1354$ \\
\hline Dois Círculos & 1 & C3 & Beta-500914 & $610 \pm 30$ & $1295-1404$ \\
\hline Dois Círculos & 4 & C8 & Beta-500917 & $500 \pm 30$ & $1398-1449$ \\
\hline Dois Círculos & 5 & C3 & Beta-500918 & $520 \pm 30$ & $1392-1443$ \\
\hline Dois Círculos & 6 & C3 & Beta-500919 & $570 \pm 30$ & $1303-1364$ \\
\hline Tocantins & 1 & C5 & Beta-500911 & $620 \pm 30$ & $1292-1400$ \\
\hline
\end{tabular}

Table 2 - AMS measurement from Boa Esperança, Dois Círculos and Tocantins Mound Villages. 
Phase: Mound Villages
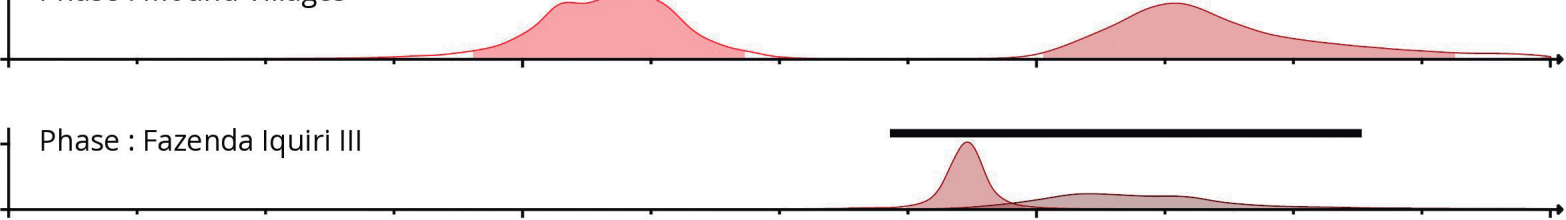

Phase : Dois Círculos IV

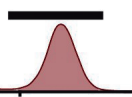

Phase : Dois Círculos V

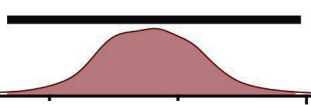

Phase : Boa Esperança

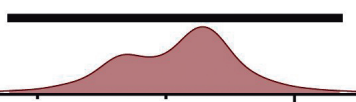

Phase : Coqueiral

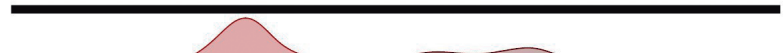

(2)

Phase : Tocantins

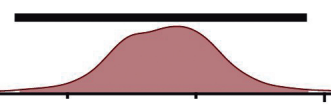

Phase : Caboquim

Phase : Fazenda Colorada
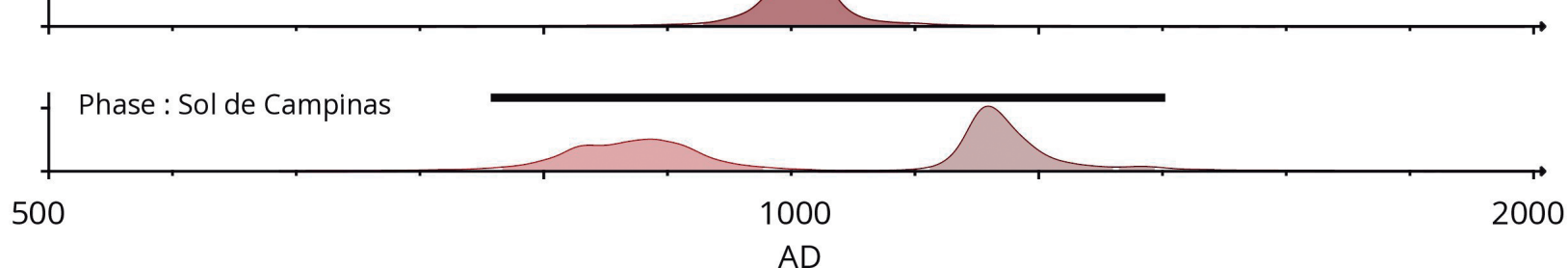

Figure 13 - Separate phase models for Mound Villages archaeological sites. 


\begin{tabular}{|c|c|c|c|}
\hline & $\begin{array}{l}\text { Phase time range } \mathrm{AD} \\
\qquad(95 \%)\end{array}$ & Begin AD (95\%) & End $\mathrm{AD}(95 \%)$ \\
\hline Fazenda Iquiri III & $1361-1812$ & 1373-1489 & $1435-1788$ \\
\hline Dois Círculos IV & $1367-1451$ & & \\
\hline Dois Círculos V & $1160-1591$ & $1215-1442$ & $1371-1566$ \\
\hline Boa Esperança & $1224-1542$ & & \\
\hline Coqueiral & $1103-1842$ & $1148-1428$ & $1428-1784$ \\
\hline Tocantins & $1202-1478$ & & \\
\hline Caboquinho & $1146-1868$ & 1169-1309 & $1403-1834$ \\
\hline Fazenda Colorada & $1160-1368$ & & \\
\hline Sol de Campinas & $950-1623$ & $958-1221$ & $1390-1617$ \\
\hline
\end{tabular}

Table 3 - Posterior dates for the phase models of individual sites.

\section{SUMMARY}

The modelling of the available radiocarbon dates from nine mound villages sites in southeastern Acre state, Brazil, establishes the beginning of this archaeological tradition in this region of south-western Amazonia around AD 952-1216. Nine dates from ten construction phases at the Caboquinho site documents the longest succession of occupations from about $\mathrm{AD}$ 1169-1309 to colonial times. The stratigraphy of the test units reported in this study confirms previous results (Neves et al. 2016, Saunaluoma, Pärssinen \& Schaan 2018) indicating that mounds are the result of alternating construction and occupation episodes. The locality of Dois Circulos showcases the complex superposition of architectural forms found in these sites including circular geoglyphs with attached rectangular compounds, roads, as well as circular and rectangular mound villages. Dates from the Dois Círculos IV Rectangular Mound Village AD 1367-1451 indicates that Rectangular Villages are broadly contemporaneous with Circular Mound Villages. Single dates from three superimposed villages in Dois Círculos V suggest the succession of village construction starting with small villages that later expanded into a larger one. The wellplanned nature of these sites, the web of roads interconnecting them, their location at a similar distance in sectors of streams and the broad contemporaneity of their occupation suggest a regionally integrated system. Future work at these sites will be able to clarify further the picture of 
settlement chronology presented here allowing 5 ACKNOWLEDGEMENTS a more precise understanding of the occupation dynamics of the Mound Villages of south-eastern Acre and other sectors of the southern rim of the Amazon. Similarly, more extensive excavations on these sites will undoubtedly reveal in more detail the uses and construction history of the diverse mounded architecture that these sites exhibit.

This research was funded by the PAST and FUTURES projects to JI by the European Research Council (ERC) under the European Union's Horizon 2020 research and innovation programme (grant agreement No. ERC_Cog 616179 and ERC PoC_777845, respectively). 


\section{REFERENCES}

Banks, W. E. 2015. Constructing chronologies for the late middle paleolithic and upper paleolithic: limitations and means to overcome them. World Archaeology 47:585-600.

Banks, W.E. et al. 2019. An application of hierarchical Bayesian modeling to better constrain the chronologies of Upper Paleolithic archaeological cultures in France between ca. 32,000-21,000 calibrated years before present. Quaternary Science Reviews 220:188-214.

Binder, D., J. Battentier, C. Delhon, \& I. Sénépart. 2017. In pursuit of a missing transition: the Mesolithic and Neolithic radiocarbon chronology at La Font-aux-Pigeons rockshelter. Antiquity 91:605-620.

Carson, J. F. et al. 2014. Environmental impact of geometric earthwork construction in pre-Columbian Amazonia. Proceedings of the National Academy of Sciences 111:10497-10502.

Souza, J.G. et al. 2019. Climate change and cultural resilience in late pre-Columbian Amazonia. Nature ecology \& evolution 3:1007-1017.

Souza, J. G. et al. 2018. Pre-Columbian earth-builders settled along the entire southern rim of the Amazon. Nature communications 9:1-10.

Heckenberger, M. J. et al. 2008. Pre-Columbian urbanism, anthropogenic landscapes, and the future of the Amazon. Science 321: 1214-1217.

Iriarte, J. 2006. Landscape transformation, mounded villages and adopted cultigens: the rise of early Formative communities in south-eastern Uruguay. World Archaeology 38:644-663.

Iriarte, J. et al. 2020. Geometry by design: contribution of lidar to the understanding of settlement patterns of the mound villages in SW Amazonia. Journal of Computer Applications in Archaeology 3:151-170 
Lanos, P., A. Philippe. 2017. Event date model: a robust Bayesian tool for chronology building. Hal:01643509.

Neves, E. et al. 2016. Pesquisa e Formação nos Sítios Arqueológicos Espinhara e Sol de Campinas do Acre - PESC. Iphan. Relatório Final. Inédito.

Prümers, H., C. Jaimes Betancourt. 2014. 100 años de investigación arqueológica en los Llanos de Mojos. Arqueoantropológicas 4:11-54.

Ramsey, C.B. 2009. Dealing with outliers and offsets in radiocarbon dating. Radiocarbon 51:1023-1045.

Saunaluoma, S. 2010. Pre-Columbian earthworks in the Riberalta region of the Bolivian Amazon. Amazônica - Revista de Antropologia 2 (1): 106-138.

Saunaluoma, S., N. Anttiroiko, \& J. Moat. 2019. UAV survey at archaeological earthwork sites in the Brazilian state of Acre, southwestern Amazonia. Archaeological Prospection 26:325 - 331.

Saunaluoma, S., M. Pärssinen, \& D.P. Schaan. 2018. Diversity of Pre-colonial Earthworks in the Brazilian State of Acre, Southwestern Amazonia. Journal of Field Archaeology 43:362 - 379.

Schwarz, F.A., J.S. Raymond. 1996. Formative settlement patterns in the Valdivia Valley, S.W. Coastal Ecuador. Fournal of Field Archaeology 23:205-224.

Walker, J.H. 2018. Island, River, and Field: Landscape Archaeology in the Llanos de Mojos. Albuquerque: University of New Mexico Press.

Wüst, I., C. Barreto. 1999. The ring villages of central Brazil: a challenge for amazonian archaeology. Latin American Antiquity 10:3-23. 